sion. Furthermore, before the Wendy Savage case a doctor was never able to vindicate himself or herself publicly because hearings under the HM (61)112 procedure were held in secret. Fortunately, the High Court decreed that "the maxim that 'justice must not only be done but must manifestly be seen to be done' applies in full measure" to the 190 procedure (judgment of 21 July 1986$){ }^{1}$

Derby DE3 7BW

EDWina Darnell

1 The Queen $v$ the Secretary of State ex parte Dr Royce Darnell. High Courts of Justice, Queens Bench Division, London. High Courts of Justice, Queens
Judgment given 21 July 1987.

2 Dyer C. A "sad and disturbing" case of dismissal of a consultant: DHSS overruled. Br Med f 1986;293:322-3.

3 Savage W. A savage enquiny: who controls childbirth. London: Virago, 1986

\section{Aftermath of Chernobyl}

SIR,-In your Medical News (28 March, p 843) you state incorrectly that "the predicted number of extra cancers due to the Chernobyl accident is about 1000." The National Radiological Protection Board's (NRPB) report makes it clear that this is the number of extra fatal cancers predicted for the European Community. ${ }^{1}$

The report quotes a figure of 2000 for the number of thyroid cancers, and states as an assumption that $5 \%$ of these would be fatal. No figure is given for the number of non-fatal cancers likely to be caused by radionuclides other than iodine-131. The number of non-fatal cancers due to these radionuclides (principally caesium-137 and caesium-134) may be obtained from the board's dose estimates by assuming that the number of extra non-fatal cancers is likely to be roughly equal to the number of fatal cancers. This is the assumption made in the United Nations report, ${ }^{2}$ which is the source of the NRPB's cancer risk estimates. This would imply another 1000 non-fatal cancers.

Thus the predicted number of extra cancers in the European Community, based on the board's assumptions, should be 4000 (2000 mostly nonfatal thyroid cancers from iodine-131 and 1000 fatal cancers and 1000 non-fatal cancers from other radionuclides). This calculation leaves out of account the fact that the cancer risk estimates used in the NRPB paper are a matter of dispute. For example, Radford, who chaired the committee on the biological effects of ionising radiation, argued for a cancer risk estimate four times higher than that used in the NRPB paper. ${ }^{3}$

We should, of course, remember that the NRPB paper refers only to the part of Europe in which the accident did not take place.

London SE13 7PL

MARTIN DACE

1 Morrey M, Brown J, Williams JA, et al. A preliminary assessmen of the radiological impact of the Chernobyl reactor accident on the population of the European Communiry. Harwell: National population of the European Communia.

2 United Nations Scientific Committee on the Effects of Atomic Radiation (UNSCEAR). Sources and effects of ionising radiation. New York: United Nations, 1977:6.

3 Radford EP. In: Committee on the biological effects of ionising radiations. The effects on populations of exposure to low levels of ionising radiation. Washington: National Academy Press, 1980:249.

\section{Retiring}

SIR,-Dr Andrew Smith's Personal View (28 March, p 834) was a sad story told by a general practitioner who found himself unprepared for this event.

I retired last year and did not gradually cut down. I remember, shortly after my 65 th birthday, looking after 5400 patients alone when my partner and the trainee were on holiday. It was exhilarating, and I still worked as if trying to create a reputation. But when I did retire my mind was prepared. A chapter of my life was finished. Five days after the lovely party given for me by colleagues we went off to Spain. When we returned two months later I felt little or no curiosity about the practice because I no longer belonged. I disappeared off the face of South Norwood, and I have never had the faintest wish to return to practice. I gave my all to my patients for 31 years, and would now hate to do a locum. A doctor who feels grateful for the crumbs of locum work is feeding through an occluding umbilical cord

I found that I had been culturally and intellectually starved, even by so broad a subject as medicine. I was ignorant of any literature other than medical literature. Now I enjoy reading Blasco Ibañez in Spanish, and I am trying this year to read as much Russian literature as I can. There is in fact too little time for all I want to do, and I truly wonder how I ever bore with the hours listening to the unhappiness of my patients. I would advise doctors to put everything into their practice certainly; bu never let medicine dominate to the extent that you cannot leave it alone. Do not make the gratitude of your patients a source of too much satisfaction, nor imagine you are deeply loved by your patients.

I hope Dr Smith's frank Personal View will no deter others from retiring. My only complaint is that 65 is rather late. Would that I could have afforded it five or ten years earlier.

\section{KeITH ThOMPSON}

Croydon CR0 5NS

\section{Chlormethiazole and alcohol: a lethal cocktail}

SIR,-Dr Gordon T McInnes provides a timely warning about the dangers of using chlormethiazole to treat the alcohol withdrawal syndrome especially in outpatients; but he does not discuss the use of drugs other than the sedative-hypnotic group in this context (7 March, p 592).

Carbamazepine has been found to be effective in treating alcohol withdrawal, including delirium tremens, and compares well with chlormethiazole in double blind comparisons. ${ }^{12}$ Although sometimes combined with small doses of benzo diazepines, carbamazepine is effective without adjunctive medication ${ }^{3}$ and offers the advantage of a rapid return to work ${ }^{4}$ or early induction into an alcoholism treatment programme. Its major advantages over chlormethiazole and the benzodiazepines are that it induces neither tolerance nor dependence and suffers no toxic interaction with alcohol.

Clonidine has also been used with some success to treat alcohol withdrawal. ${ }^{5}$ Like carbamazepine, it carries the advantages of shortening hospital stay, lack of toxicity in combination with alcohol, and absence of liability to dependence or misuse ("rebound" hypertension does not appear to be a problem in short term use ${ }^{6}$ ). When there is a history of seizures it may be wise to use adjunctive prophylactic anticonvulsants until clonidine is more fully evaluated. Lofexidine, a clonidine analogue with less hypnotic effect, has also been used with some benefit. ${ }^{6}$

Neither carbamazepine nor clonidine holds a product licence in Britain for use in managing alcohol withdrawal. But there are enough published reports in support of the use of carbamazepine for this purpose, and it has advantages over more traditionally used drugs. Further research is called for in developing these (or other) treatments of the alcohol withdrawal syndrome in an effort to avoid the dangers associated with traditional regimens.

Christopher COOK MAURICE LIPSEDGE

Guy's Hospital,

London SE1

1 Ballenger JC, Post RM. Carbamazepine in alcohol withdrawal syndromes and schizophrenia psychoses. Psychopharmacol Bull 1984;20:572-84.

2 Ritola E, Malinen L. A double blind comparison of carbamazepine and chlormethiazole in the treatment of alcoho withdrawal syndrome. Acta Psychiatr Scand 1981;64:254-9.

3 Agricola $R$, Mazarino $M$, Urani $R$. Treatment of acute alcohol withdrawal syndrome with carbamazepine: a double blind comparison with tiapride. $\mathcal{F}$ Int Med Res 1982;10:160-5.

4 Bond WS. Psychiatric indications for clonidine: the neuropharmacologic and clinical basis. $f$ Clin Psychopharmacol 1986;6:81-7.

5 Gold MS, Redmond DE, Kleber. HD. Clonidine blocks acute opiate withdrawal symptoms. Lancet 1978;ii:599-602.

6 Brunning J, Mumford JP, Keaney FP. Lofexidine in alcohol withdrawal states. Alcohol and Alcoholism 1986;21:167-70.

\section{Failure to observe statistical guidelines}

SIR,-In the past few years articles have appeared in the $B M F$ giving statistical guidelines for contributors to medical journals ${ }^{1}$ and in particular encouraging the use of confidence intervals. ${ }^{2}$ Consequently one would hope that the quality of statistical content in published articles would improve. Unfortunately in a recent edition (28 February) three articles appear which include inappropriate statistical methods.

All three articles (pp 531, 534, 540) include examples of paired data: a crossover trial of placebo versus slow sodium, comparison of alcoholic brains matched with controls, and measurement of urinary frequency before and after treatment. The correct analysis of this type of data should be based on paired differences. It is not always clear from their reports what these authors have done, but in the presentation of these data the pairing is ignored. The data are presented with standard errors or standard deviations for each group separately, whereas a more appropriate statistic to show is the confidence interval for the change in the measurement.

On the basis of this particular edition it appears that the statistical guidelines are not being followed by some authors and, perhaps more importantly, are not being enforced by referees.

Cecilia C A Macintyre GILLIAN M RAAB

Medical Statistics Unit,

Medical Statistics

Medical School,

1 Altman DG, Gore SM, Gardner MJ, Pocock SJ. Statistical guidelines for contributors to medical journals. $\mathrm{Br}$ Med $\mathrm{f}$ 1983;286:1489-93.

2 Gardner MJ, Altman DG. Confidence intervals rather than $P$ values: estimation rather than hypothesis testing. $\mathrm{Br}$ Med $\mathcal{F}$ 1986;292:746-50.

Congenital rubella in babies of south Asian women in England and Wales

SIR,-Dr Elizabeth Miller and coworkers (21 March, $p$ 737) suggests that ethnic minority groups less well defined than Asian immigrants may also be at increased risk of congenital rubella. Our findings support this suggestion.

Antenatal rubella serology by single radial haemolysis of patients attending our practice for maternity services from March 1986 to February 1987 was reviewed. The two largest ethnic groups were white women of United Kingdom origin and Malaysians (postgraduate students or their spouses). Of the 19 white women, one was re- 